\title{
Evaluation of the effectiveness of two different methods for the prevention of microbial colonization in nebulizers: Randomised controlled trial
}

\section{Nebulizerlerde mikrobiyal kolonizasyonun önlenmesi için iki farklı yöntemin etkinliğinin değerlendirilmesi: Randomize kontrollü çalışma}

\author{
Bengü ÇETINKAYA, Sibel Serap CEYLAN \\ Pamukkale Üniversitesi Să̆lık Bilimleri Fakültesi Çocuk Să̆lı̆̆ı ve Hastalıkları Hemşireliği Ana Bilim Dalı, Denizli
}

\begin{abstract}
Objective: In this study two different methods were used to prevent microbial colonisation of nebulizer elements and the results were evaluated.

Methods: The study was conducted as a randomized controlled semi-experimental study. The data were collected at the pediatrics department of a hospital in the city in western Turkey. A total of 120 pediatric patient using nebulizer treatment at least twice daily and their mothers were included in the study. The pediatric patients were divided into 3 groups. In one group no intervention was made (control group). In another group, nebulizer masks and sets were changed once every 24 hours. In the third group, masks were washed once daily in soap and water. In all groups swab samples were taken every 24 hours and examined under laboratory conditions.

Results: Results showed that there was $10.8 \%$ microbial growth in the control group and $2.5 \%$ microbial growth in the 24-hour change group. No growth was detected in the wash group.

Conclusion: As a result of this study, it is recommended that nebulizer elements are washed once daily with soap and water and dried on a clean towel in order to prevent contamination.
\end{abstract}

Keywords: Inhalation, nebulizers, disinfection, pediatrics

ÖZ

\begin{abstract}
Amaç: Bu çalışmada, nebulizatör parçalarında mikrobiyal kolonizasyonu önlemek için iki farklı yöntem uygulanmış ve sonuçları değerlendirilmiştir.

Yöntem: Çalışma yarı deneysel randomize kontrollü bir çalışmadır. Çalışma verileri Türkiye'nin batısında bulunan bir şehirdeki hastanelerin çocuk sağlığı ve hastalıkları kliniklerinde toplanmıştır. Çalışma kapsamına günde en az 2 kez nebul tedavisi alan 120 çocuk hasta ve annesi dahil edilmiştir. Araştırma kapsamına alınan çocuklar 3 gruba ayrılmıştır. Bir gruba girişim uygulanmamıştır (kontrol grubu). Bir grubun nebul maskeleri ve setleri 24 saatte bir değiştirilmiştir. Bir grubun maskeleri ise günde bir kez su ve sabunla yıkanmıştır. Tüm grupların maske ve setlerinden 24 saatte bir sürüntü örneği alınıp laboratuvar ortamında değerlendirilmiştir.

Bulgular: Araştırma sonucunda kontrol grubunda \%10,8, 24 saatte bir değişim yapılan grupta $\% 2,5$ oranında mikrobiyal üreme saptanmıştır. Yıkama grubunda ise hiç üreme saptanmamıştır.

Sonuç: Sonuç olarak, kontaminasyonu önlemek için nebulizatör parçaların günde bir kez sabun ve suyla yıkanması ve temiz bir havlu üzerinde kurutulması önerilmektedir.

Anahtar kelimeler: Inhalasyon, nebulizer, dezenfeksiyon, pediatri

Alındığı tarih: 22.03.2017

Kabul tarihi: 24.10 .2017

Yazışma adresi: Doç. Dr. Bengü Çetinkaya, Pamukkale Üniversitesi Sağlık Bilimleri Fakültesi Kınıklı Kampüsü, Denizli - Türkiye

e-mail: bcetinkaya@pau.edu.tr
\end{abstract}

\section{INTRODUCTION}

Nebulizers and their chambers are items of medical equipment that are used on the respiratory tract and come into indirect contact (semi-critical) with respiratory mucosa ${ }^{(1)}$. Delivery of drugs using nebulizer is preferred because of the local and rapid effect, and fewer side effects with lower doses. The risk of infection, overdose or adverse effects during delibvery of the drugs are the disadvantages of the 
use of a nebulizer ${ }^{(2)}$.

The risk of contamination is high after nebulizer use ${ }^{(3,4)}$. Nebulizer contamination can cause various lower respiratory tract infections ${ }^{(4,5)}$. The cleaning, sterilization, and disinfecting of the medical equipment used on the respiratory tract is important in terms of preventing infection in patients ${ }^{(6)}$. There are various suggestions for preventing infections caused by nebulizers. The Centers for Disease Control and Prevention and the European Respiratory Society recommend that nebulizers should be cleaned, disinfected, rinsed in sterilized water, and dried after each use ${ }^{(6,7)}$. In their study, Cobben et al. ${ }^{(8)}$ proposed that masks and sets should be changed every 24 hours. The procedures for the prevention of microbial colonization on the nebulizer equipment have been important research topics. Although the literature demonstrates significant evidence for bacterial growth in home nebulizer, which are used for chronic respiratory tract infection ${ }^{(9)}$, we could not find any literature related to contamination during short time usage. The methods for preventing infection must be simple and cost-effective. In this study, three different procedures for preventing microbial colonization of nebulizer masks and sets were applied and then the results were reviewed.

\section{RESEARCH QUESTIONS}

1. Is there a microbial colonization of nebulizer masks and sets of the control group?

2. Is there a microbial colony in the nebulizer mask and set of the experimental group 1?

3 . Is there a microbial colonization of nebulizer masks and sets of experimental group 2?

\section{MATERIAL and METHODS}

In this study, a randomized controlled semiexperimental design was used. The study was conducted at the pediatrics department of a hospital in Turkey. The pediatric ward had a 40-bed capacity with six children and their mothers were staying in this ward. The study included 120 patients aged 0-5 with bronchitis and bronchiolitis using nebulizer treatment at least twice daily and their mothers.
In order to determine the sample size of the study, the literature was examined and it was determined that the microorganism growth rate in the nebulizers ranged from $11.3 \%$ to $16.6 \%{ }^{(5,10)}$. In our study, it was estimated that $1 \%$ of the experimental group and $20 \%$ of the control group had microbial growth, and sample size was calculated as 31 patients per each group with a statistical power of $80 \%$ and a confidence interval of $95 \%{ }^{(11)}$. Considering the possibility of data loss, 40 patients were included in each group. Cramer's V was calculated to calculate the effect size of the work, and a median effect size of .23 was obtained.

The participants were divided into three groups by randomization. In the first group, the patients' nebulizer masks and sets (tube, and chamber) were changed according to the clinical routines. In the clinic where the data was collected, the same nebulizer masks and sets were used for the whole duration of the patients' stay. During this time the masks and sets were not disinfected or dried (control group). In the second group, the masks and sets were changed every 24 hours. There was no disinfecting or drying in this group either (experimental group 1). In the third group (experimental group 2), the nebulizer masks and chambers were washed with soap and water and dried once every day by the mothers. The tubes were not washed and changed (Figure 1). The researchers established the kind of soap routinely used by the mothers for their children. The mothers were educated by the researchers and also given a written copy of the washing procedure (Table 1).

The experimental groups and the control group were created by a randomization process taking into account the diagnosis, and treatment protocols (frequency, and type of medicine) for the children.

Before the first usage cultures were obtained in the control group, in experimental groups 1 and 2. In the control group and experimental group 2, the cultures were taken with swabs from the nebulizer masks, chambers, and tubes before the first usage, and after the $24^{\text {th }}, 48^{\text {th }}$, and $72^{\text {nd }}$ hour. In the experimental group 1 , the cultures were taken at $24^{\text {th }}$ hour. The culture samples were immediately placed onto a Stuart transport medium and taken to the laboratory. 

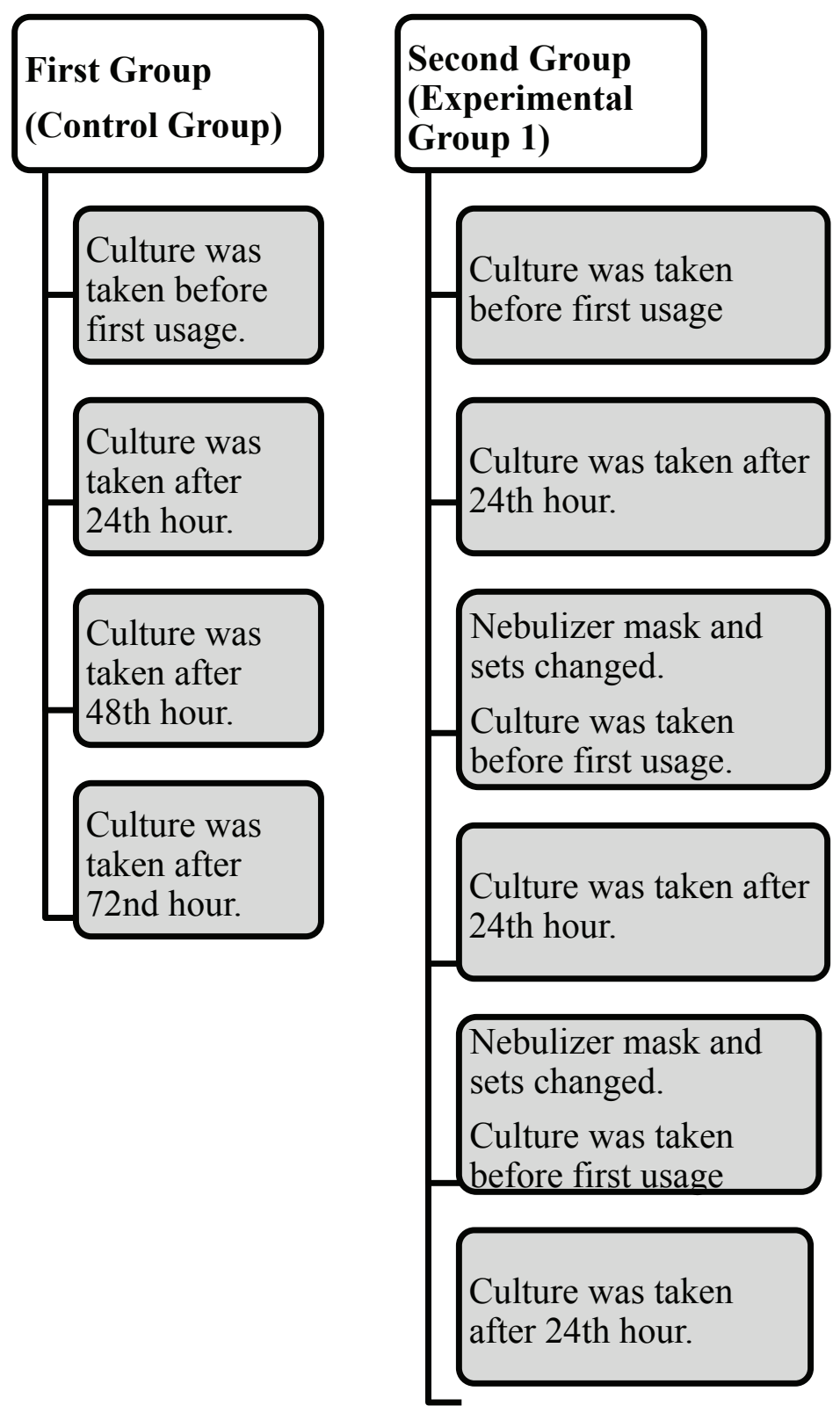

\section{Third Group \\ (Experimental \\ Group 2)}

Mothers were educated

about the washing

procedure

Culture was taken first usage

Nebulizer mask and chamber washed after 12 th hour.

Culture was taken after 24th hour.

Nebulizer mask and

chamber washed after 36th hour

Culture was taken after 48th hour.

Nebulizer mask and chamber washed after 60 th hour

Culture was taken after 72 nd hour.

Figure 1. Collection of study data.

The bacterial culture was implanted into 5\% Sheep Blood Agar Base and Eosin-Methylene Blue Agar
(EMB) and left for 48 hours at $37^{\circ} \mathrm{C}$. The bacterial pathogens grown were reported. 
Table 1. Washing procedure for mothers.

\begin{tabular}{ll}
\hline & $\begin{array}{l}\text { 1. Separate the mask from the tube } \\
\text { 2. Separate the mask from the chamber }\end{array}$ \\
After the last usage & 3. Place all the parts in a clean bowl \\
every day, please clean & except for the tubes \\
the mask and chamber & 4. Add warm water and soap and lather \\
according to the & 5. Wash all the parts \\
instructions opposite & $\begin{array}{l}\text { 6. Rinse all parts } \\
\text { 7. Dry the mask and the chamber on a } \\
\text { paper towel }\end{array}$
\end{tabular}

In the data collection, the children and their parents' introductory information form and forms with daily monitoring and result records were used. The data were collected by the researchers.

All the statistical analyses were performed by using SPSS software, version 11.5 (SPSS Inc., Chicago, IL, USA). In the data analysis, the percentage distributions and the homogeneity test $(\chi 2)$ were used to assess the descriptive characteristics of the participants in the control and experimental groups, and percentage distributions were used for the microbial growth rates. The statistical significance was set at $\mathrm{p}<0.05$.

The required permission to conduct the study was obtained from the University Medical Ethics board. Information about the study was given to the participating families and their written consent was obtained.

\section{RESULTS}

The mean age of the patients included in the study was established to be $12.96 \pm 10.87$ months. The mean age of the mothers was $27.98 \pm 5.24$, and their mean length of school education was found to be $6.55 \pm 3.62$ years.

Randomization was applied with regards to the diagnosis, and treatment protocol (frequency, and type of the medication) of the children receiving the nebulizer treatment in the control and experimental groups (Table 2).

Of the culture samples taken from the masks and sets, bacterial growth was detected in the masks only. The analysis of the bacterial growth in the experimental and control groups established that the growth
Table 2. Characteristics of the children under nebulizer treatment.

\begin{tabular}{|c|c|c|c|}
\hline $\begin{array}{l}\text { Characteristics of } \\
\text { the children }\end{array}$ & $\begin{array}{c}\text { Control } \\
\text { Group } \\
\text { n }(\%)\end{array}$ & $\begin{array}{c}\text { Experimental } \\
\text { Group } 1 \\
\text { n }(\%)\end{array}$ & $\begin{array}{c}\text { Experimental } \\
\text { Group } 2 \\
\text { n }(\%)\end{array}$ \\
\hline \multicolumn{4}{|l|}{ Gender } \\
\hline Female & $10(25)$ & $9(22.5)$ & $13(32.5)$ \\
\hline \multirow[t]{2}{*}{ Male } & $30(75)$ & $31(77.5)$ & $27(67.5)$ \\
\hline & \multicolumn{3}{|c|}{$\mathrm{X}^{2}=1.108 ; \mathrm{p}>0.05$} \\
\hline \multicolumn{4}{|l|}{ Diagnosis } \\
\hline Bronchitis & $12(30)$ & $13(32.5)$ & $21(52.5)$ \\
\hline \multirow{2}{*}{ Bronchiolitis } & $28(70)$ & $27(67.5)$ & $19(47.5)$ \\
\hline & \multicolumn{3}{|c|}{$\mathrm{X}^{2}=5.147 ; \mathrm{p}>0.05$} \\
\hline \multicolumn{4}{|l|}{$\begin{array}{l}\text { Previously received } \\
\text { nebulizer treatment }\end{array}$} \\
\hline Yes & $14(35)$ & $22(55)$ & $20(50)$ \\
\hline \multirow[t]{2}{*}{ No } & $26(65)$ & $18(45)$ & $20(50)$ \\
\hline & \multicolumn{3}{|c|}{$\mathrm{X}^{2}=3.482 ; \mathrm{p}>0.05$} \\
\hline \multicolumn{4}{|l|}{ Nebulizer treatment } \\
\hline given at home & $6(15)$ & $6(15)$ & $17(42.5)$ \\
\hline Yes & $34(85)$ & $34(85)$ & $23(57.5)$ \\
\hline No & \multicolumn{3}{|c|}{$\mathrm{X}^{2}=11.004 ; \mathrm{p}<0.05$} \\
\hline \multicolumn{4}{|l|}{ Frequency of } \\
\hline At least 2 times & $39(97.5)$ & $40(100)$ & $40(100)$ \\
\hline 3 or more times & $X^{2}=2.017 ;$ & $\mathrm{p}>0.05$ & \\
\hline \multicolumn{4}{|l|}{$\begin{array}{l}\text { Type of aerosol } \\
\text { medicine }\end{array}$} \\
\hline Salbutamol & $24(60)$ & $26(65)$ & $20(50)$ \\
\hline \multirow{2}{*}{$\begin{array}{l}\text { Salbutamol+ } \\
\text { budesonide }\end{array}$} & $16(40)$ & $14(35)$ & $20(50)$ \\
\hline & \multicolumn{3}{|c|}{$\mathrm{X}^{2}=1.920 ; \mathrm{p}>0.05$} \\
\hline \multicolumn{4}{|l|}{ Antibiotic treatment } \\
\hline Yes & $38(95)$ & $32(80)$ & $32(80)$ \\
\hline \multirow[t]{2}{*}{ No } & $2(5)$ & $8(20)$ & $8(20)$ \\
\hline & $X^{2}=4.706$ & $\mathrm{p}>0.05$ & \\
\hline Total & $40(100)$ & $40(100)$ & $40(100)$ \\
\hline
\end{tabular}

occurred after 48 and 72 hours in the control group and growth of Staphylococcus aureus and Pseudomonas species was demonstrated (Table 3).

In the experimental group 1 growth of coagulasenegative Staphylococcus species was detected at the first and the second change of the nebulizer (Table 4).

Any microbial growth was not detected in the experimental group 2 (Table 5). There was no significant difference between the education of the mothers and presence of bacterial growth in the nebulizer masks and sets $(\mathrm{p}<0.05)$. 
Table 3. Distribution of control group microbial contamination.

\begin{tabular}{lccc}
\hline & \multicolumn{2}{c}{ Control Group } & \\
\cline { 2 - 3 } Monitoring & Yes (\%) & No (\%) & Microorganism \\
\hline Before usage & - & $40(100)$ & - \\
$24^{\text {th }}$ hours & - & $40(100)$ & - \\
$48^{\text {th }}$ hours & $2(5)$ & $38(95)$ & Staphylococcus aureus \\
$72^{\text {nd }}$ hours & a $2(5.7)$ & & Staphylococcus aureus \\
& b1 $1(2.9)$ & $31(88.5)$ & \\
& $1(2.9)$ & & Pseudomonas species
\end{tabular}

agrowth continuing since $48^{\text {th }}$ hours; ${ }^{\text {b }}$ growth at $72^{\text {nd }}$ hours

Table 4. Distribution of experimental group 1 microbial contamination.

\begin{tabular}{|c|c|c|c|}
\hline \multirow[b]{2}{*}{ Monitoring } & \multicolumn{2}{|c|}{$\begin{array}{c}\text { Experimental group } 1 \\
\text { (Change every } \\
24 \text { hours })\end{array}$} & \multirow[b]{2}{*}{ Microorganism } \\
\hline & Yes $(\%)$ & No $(\%)$ & \\
\hline$* 1^{\text {st }}$ change & $1(2.5)$ & $39(97.5)$ & $\begin{array}{l}\text { Coagulase-negative } \\
\text { Staphylococcus species }\end{array}$ \\
\hline$* 2^{\text {nd }}$ change & $1(2.7)$ & $36(97.3)$ & $\begin{array}{l}\text { Coagulase-negative } \\
\text { Staphylococcus species }\end{array}$ \\
\hline$* 3^{\text {rd }}$ change & - & $35(100)$ & - \\
\hline
\end{tabular}

*Masks and sets changed every 24 hours

Table 5. Distribution of experimental group 2 microbial contamination.

\begin{tabular}{lccc}
\hline & \multicolumn{2}{c}{ Control Group } & \\
\cline { 2 - 3 } Monitoring & Yes (\%) & No (\%) & Microorganism \\
\hline Before use & - & $40(100)$ & - \\
$24^{\text {th }}$ hours & - & $40(100)$ & - \\
$48^{\text {th }}$ hours & - & $36(100)$ & - \\
$72^{\text {nd }}$ hours & - & $31(100)$ & - \\
\hline
\end{tabular}

\section{DISCUSSION}

The aim of nebulization treatment is to deliver the drug in a liquid form rapidly into the bronchioli and alveoli in the form of respirable particles and to enable the accumulation of particles smaller than five microns into the lungs ${ }^{(12)}$. According to their species, the dimensions of the microorganisms vary from 0.01 to 100 microns ${ }^{(13)}$. In these circumstances the improper use of nebulizers can lead to microorganisms reaching the lungs. Our study findings supported that bacterial growth occurs in the control group at $48^{\text {th }}$ and $72^{\text {nd }}$ hours, and accordingly Staphylococcus aureus and pseudomonas species were isolated. The growth rate was $10.8 \%$ in this group.

In a study which monitored nebulizers for 24-72 hours, $10.5 \%$ of a total $11.4 \%$ cases growth of gram negative bacilli mainly Pseudomonas aeruginosa was found ${ }^{(5)}$.

In our study, a change was made every 24 hours in experimental group 1 . In this group, a growth at a rate of $2.5 \%$ was seen at the first change and at a rate of $2.7 \%$ at the second change. The similarity between these rates is noteworthy. The growth of coagulasenegative Staphylococci was seen at both changes.

In another study, in three of the culture samples taken from 150 nebulizers at the $24^{\text {th }}$ hour, (2\%) coagulase-negative Staphylococcus was isolated ${ }^{(12)}$. Other studies concerning nebulizers have observed Pseudomonas species and coagulase-negative Staphylococcus growth in nebulizer parts ${ }^{(4,9,10,15,16)}$. Some species of Pseudomonas, Streptococcus and Staphylococcus can result in serious respiratory tract infections such as pneumonia ${ }^{(17-19)}$.

In our study there was no microbial growth in the washing group (experimental group 2). Humidity creates a suitable environment for the growth of bacteria ${ }^{(20)}$. The studies conducted have suggested that nebulizer parts be kept away from humidity in order to prevent contamination. In a study, Hutchinson et al. ${ }^{(9)}$ emphasized that although bacterial growth is possible in nebulizers after disinfecting procedures such as washing, there was minimal or no bacterial growth when parts were dried after being washed. Blau et al. (3) also specified in their study that the washing and drying of nebulizers reduce the rate of contamination.

In addition to this, Cohen et al. (4) found that the rate of contamination can be reduced by washing and drying nebulizer masks and chambers after every usage. Furthermore, Reychler et al. ${ }^{(14)}$ recommended washing with tap water and detergent, rinsing in tap water and drying on a clean towel of all nebulizer parts after every usage. The study of Jakobson et al. ${ }^{(15)}$ supported the knowledge that fewer bacteria grow in dry environments. These studies support our 
study's findings. In the control group and experimental group 1, the microbial growth may be linked to a moist environment.

In our study, in the groups where no disinfecting or drying procedures were applied, microbial growth was observed; whereas in the group where washing and drying were performed, no microbial growth was detected.

Improper cleaning/changing of nebulizers leads to contamination and the risk of lower respiratory tract infections. Our study's findings demonstrate that the once-daily washing and drying of nebulizer parts prevents contamination. Health education is one of the important tasks of the Pediatric Nurse. Using this function, the nurse trains and counsels the child and family to protect them from illness. It is therefore recommended that hospital procedures regarding nebulization should be established and that pediatric nurses should provide training to children's primary caregivers on the use of nebulizers.

As there is a procedure to prevent infection in nebulizer masks and sets in other centers, it is the limit of the research to be carried out in one center. This is also a strong point of the research in terms of controlling the environmental factors.

\section{ACKNOWLEDGMENTS}

Source of Funding Statement: The study was supported fully by the Pamukkale University Scientific Research Projects Coordination Unit.

\section{REFERENCES}

1. Arman D, Arda B, Çetinkaya Şardan Y, Bal Kayacan Ç, Esen F, Topeli İskit A, et al. Sağllk hizmeti ile ilişkili pnömoninin önlenmesi k1lavuzu. Hastane Enfeksiyonlarl Dergisi 2008;12:1-14.

2. O'Malley CA. Device cleaning and infection control in aerosol therapy. Respir Care 2015;60:917-927. https://doi.org/10.4187/respcare.03513

3. Blau H, Mussaffi H, Zahav MM, Prais D, Livne M, Czitron $\mathrm{BM}$, et al. Microbial contamination of nebulizers in the home treatment of cystic fibrosis. Child Care Health Dev 2007;33:491-495.

https://doi.org/10.1111/j.1365-2214.2006.00669.x

4. Cohen HA, Kahan E, Cohen Z, Sarrell M, Beni S, Grosman $\mathrm{Z}$, et al. Microbial colonization of nebulizers used by asthmatic children. Pediatr Int 2006;48:454-458. https://doi.org/10.1111/j.1442-200X.2006.02252.x

5. Roberts F, Cockcroft W, Johnson H, Fishwick T. The infecti- on hazard of contaminated nebulizers. Can Med Assoc J 1973;108:53-56.

6. Tablan OC, Anderson LJ, Besser R, Bridges C, Hajjeh R. Guidelines for preventing healthcare-associated pneumonia, 2003. MMWR 2004;53(RR-3):1-36.

7. Boe J, Dennis J, O'Driscoll B, Bauer T, Carone M, Dautzenberg B, et al. European Respiratory Society Guidelines on the use of nebulizers Guidelines prepared by a European Respiratory Society Task Force on the use of nebulizers. Eur Respir J 2001;18:228-242. https://doi.org/10.1183/09031936.01.00220001

8. Cobben NAM, Drent M, Jonkers M, Wouters EFM, Vaneechoutte M, Stobberingh EE. Outbreak of severe Pseudomonas aeruginosa respiratory infections due to contaminated nebulizers. J Hosp Infec 1996;33:63-70. https://doi.org/10.1016/S0195-6701(96)90030-4

9. Hutchinson GR, Parker S, Pryor JA, DuncanSkingle F, Hoffman PN, Hodson ME, et al. Home-use nebulizers: A potential primary source of Burkholderia cepacia and other colistin-resistant, gram-negative bacteria in patients with cystic fibrosis. J Clin Microbiol 1996;34:584-587.

10. Reychler G, Leonard A, Van Ossel C, Godding V, Gigi J, Simon A, et al. Impact of hypochlorite-based disinfection on bacterial, contamination of cystic fibrosis patients' homenebulisers. J Hos Infect 2009;72:351-357. https://doi.org/10.1016/j.jhin.2009.05.011

11. DSS Research. Avaliable from: https://www.dssresearch. com/knowledgecenter/toolkitcalculators/statisticalpowercalculators.aspx

12. O'Callaghan $\mathrm{C}$. How to get drugs into the respiratory tract. Arch Dis Child 1993;68:441-3. https://doi.org/10.1136/adc.68.4.441

13. Sharma PD. Microbiology, Rakesh Kumar Rastogi for Rastogi Publications, Meerut, India, 2007.

14. O'Malley CA, VandenBranden SL, Zheng XTT, Polito AM, McColley SA. A day in the life of a nebulizer: Surveillance for bacterial growth in nebulizer equipment of children with cystic fibrosis in the hospital setting. Respir Care 2007;52:258262.

15. Jakobsson BM, Onnered AB, Hjelte L, Nystrom B. Low bacterial contamination of nebulizers in home treatment of cystic fibrosis patients. J Hosp Infec 1997;36:201-207. https://doi.org/10.1016/S0195-6701(97)90195-X

16. Reychler G, Aarab K, Van Ossel C, Gigi J, Simon A, Leal T, et al. In vitro evaluation of efficacy of 5 methods of disinfection on mouthpieces and facemasks contaminated by strains of cystic fibrosis patients. J Cyst Fibros 2005;4:183-187. https://doi.org/10.1016/j.jcf.2005.06.001

17. Rosenthal VD, Maki DG, Salomao R, Alvarez-Moreno C, Mehta Y, Higuera F, et al. Device-associated nosocomial infections in 55 intensive care units of 8 developing countries. Ann Intern Med 2006;145:582-591. https://doi.org/10.7326/0003-4819-145-8-200610170-00007

18. Dima S, Kritsotakis EI, Roumbelaki M, Metalidis S, Karabinis A, Maguina N, et al. Device-associated nosocomial infection rates in intensive care units in Greece. Infect Control Hosp Epidemiol 2007;28:602-605. https://doi.org/10.1086/513618

19. Tiewsoh K, Lodha R, Pandey RM, Broor S, Kalaivani M, Kabra SK. Factors determining the outcome of children hospitalized with severe pneumonia. BMC Pediatr 2009;9. https://doi.org/10.1186/1471-2431-9-15

20. Atlas RM. Principles of Microbiology, McGraw-Hill Companies, New York, 1997. 